\title{
Human Security: An Analysis of the Dissemination of an Idea in World Politics
}

\author{
ŠÁRKA WAISOVÁ
}

\section{sciendo}

Politics in Central Europe (ISSN: 1801-3422)

Vol. 14, No. 3

DOI: $10.2478 /$ pce-2018-0019

\begin{abstract}
The study considers the dissemination of the idea of human security including the means - trajectories and spaces - by which it has been spread and reproduced in international politics. My aim is to illuminate the agents behind this dissemination, the ways that the concept has been shared and the intellectual and institutional frameworks that have enabled its existence. I conclude that the idea of human security arose from the UN system, particularly the United Nations Development Programme's offices. It was disseminated with the assistance of "human security friends," i.e. Japan, Canada and Norway and several prominent scholars, high-ranking policy-makers and UN officers. Nevertheless, despite these efforts, human security has not found a following worldwide. It was embedded in part of the UN system where it has remained powerful and been reproduced. Outside the UN system, however, even its most active and devoted promoters have abandoned the concept. The number of these supporters has dwindled, the idea has lost its power and the spaces where it is reproduced are limited.
\end{abstract}

Keywords: human security, dissemination of an idea, United Nations, Canada, Japan.

Human security (HS) has been widely discussed by scholars as well as policy-makers over the last two decades. Academic analyses include debates about the conceptualisation of HS (Waisová 2003), its relevance for the contemporary world (Paris 2001; Dissent 2007), its measurement and mapping (King - Murray 2002; Owen 2010) and its place in security studies (Gasper 2004; Newman

1 I would like to thank West Bohemian University (grant SGS-2018-011), which supported the research and work on this article. 
2010; Krause 2013). Several academic journals devoted to human security issues have sprung into existence ${ }^{2}$ and many other journals, while lacking HS in their name, have declared an interest in HS-focused articles. ${ }^{3}$ Human security has also generated broad interest in the policy sphere. It has emerged as a priority on Canadian, Norwegian and Japanese foreign policy agendas, found a place in the EU lexicon and become a driving force for a number of UN agencies and bodies. Special HS advisory and policy-making bodies have been established and HS coalitions and platforms have arisen (for more information, see below and Figure 1). Additionally, new university HS research centres and degree programmes have been created (see Appendix 1).

All of this demonstrates that HS has become more than "hot air" (Paris 2001). It is a powerful normative framework, a policy motif and tool, a concept (and some would even claim a paradigm), a means of tackling issues, a set of practices and positions, a strategy, a critical model and a field of knowledge which is even subject to university certification.

The fascination of the academic community and policy-makers with human security has led to lively debates about the concept including questions about how wide or narrow its scope should be, which threats it should include, how it should translate into policy, how that policy should be implemented and the possible motivations and actions of HS friends and opponents. While some of these issues (for example, the question of what precisely is being secured and what constitutes human security as a condition) have been addressed, others remain unexplored. One of the least understood subjects is the development of ideas of human security, or more specifically, how these ideas entered the public policy debate and became part of a policy trend that spread worldwide and was eventually institutionalised in organisations and practices. Did these concepts arise, as the conventional wisdom might suggest, from objective threats and conditions inherent in the harsh contemporary world? Were they socially constructed and used by the North to manipulate and control the South? With a few exceptions (Gasper 2005; Chandler 2008; Matlary 2008; Newman 2010; Krause 2013), these questions have been met by silence. We also lack studies about the deeper impulses behind the adoption of the human security concept and the ways that institutions and scholars have endorsed and perpetuated certain modes of HS thinking and practice. All these questions are particularly important at a time when - after almost three decades in international politics - HS seems to have been marginalised as a strategic narrative and holistic framework (Martin - Owen 2010). Understanding the life cycle of the idea and its particular phases could, thus, be of enormous benefit to scholars and policy-makers.

2 See, e.g., Journal of Human Security, Journal of Human Security Studies, Journal of Migration and Human Security, Journal of Human Security \& Resilience and PRAXIS. The Fletcher Journal of Human Security.

3 One such publication is Conflict, Security \& Development. 
The goal of the present analysis is to identify those responsible for disseminating the human security idea as well as the means - i.e. trajectories and spaces - through which it has been spread and reproduced within international politics. I aim to shed light on the agents behind the concept's dissemination and (re)production along with how it has been shared and the intellectual and institutional frameworks that have enabled its existence. As Finnemore and Sikkink (1998) have noted, whatever their genesis, new norms and ideas require not only a "norm entrepreneur" but also an institutional platform. Answering these questions can help us make sense of why and how HS found a place in the sun and what role it has played in the history of post-Cold War politics. Exploring the life cycle and different faces of this single productive, popular and oft-cited idea can tell us more about the social, political and spatial conditions that have accompanied it. It can also highlight the interplay between the academy and politics and reveal how power shapes ideas and how ideas work in tandem with power.

The structure of this article is as follows: The first section introduces a theoretical and methodological framework for my analysis. As I have indicated, the central questions of this article are: Who was behind the rise of HS as an idea and policy trend? And how was the idea reproduced? The best methodological strategy to address questions of "how" and "who" is genealogy. A genealogical approach is, thus, applied in the second part of this study. This section maps the actors who have disseminated and reproduced the HS concept as well as the trajectories and spaces of this dissemination and reproduction. In this way, I seek to uncover the institutional models and series of critical actions that gave rise to the idea of human security.

\section{Theoretical and methodological points of departure}

Two centuries ago, Friedrich Nietzsche (2006/1887) argued that there was no independent reality apart from human activity and he, thus, called for the replacement of science by genealogies - historical-philosophical accounts of how reality comes into being. A century later, genealogy was applied by Michel Foucault (1977), who wished to demonstrate that knowledge and power were inseparable and that there were no universal truths in history. Foucault showed how power and knowledge directly implied one another. Genealogy is a familiar research approach in International Relations (IR) and has been recognised in several publications. ${ }^{4}$ IR scholars use genealogy as a critical historical approach to interpret the social and political world. This distinctive historical research method allows them to analyse how agents and structures are constituted within

4 The key texts here are James Der Derian (1987): On Diplomacy: A Genealogy of Western Estrangement and Richard M. Price (1997): The Chemical Weapons Taboo. Other articles and books have followed in a similar vein. 
historically and culturally specific sites. This is done by drawing attention to contingency and the productive power of discourse (Vucetic 2011).

An important issue in this context has been whether genealogy can be applied to questions that do not ask "how" and, in particular, whether it can extend to questions of "who." While Foucault rejected a genealogical approach to these questions, other scholars have demonstrated that such a tactic is entirely appropriate (Vucetic 2011). Since the current study is not concerned with causation, but rather with a power analysis of the dissemination and reproduction of the HS idea and the actors who drove these processes, genealogy would seem to be the correct framework.

This work combines a genealogical approach with ethnographic methods, particularly biographical research and qualitative interviews. These methods are rounded out by analyses of the memoirs of outstanding individuals as well as their correspondence, media interviews and conference records and transcripts. Genealogy and ethnographic methods are a complementary and potentially powerful pairing; they share reflexivity and interpretative scope, enabling micro-analysis while also shedding light on the wider context. These tools can help us scrutinise practices and institutions by following the links between the personal trajectories, values and work cycles of key individuals and institutions and the agendas they adopt. At the same time, they can elucidate social interactions, group, organisational and community behaviour and perceptions, cultural contexts, cultural processes and meanings and subjective meanings (Gille -Riain 2002; Gould 2014; Stubbs 2014).

\section{Dissemination and reproduction of the HS idea: Mapping agents, trajectories and spaces}

In order to study the agents, trajectories and spaces involved in disseminating and reproducing the human security idea, this section collects key empirical data and presents it graphically. Figure 1 highlights the historical dynamics surrounding the HS concept. To this end, it maps the institutional models and organisational structures behind the concept's dissemination and reproduction and a cascade of critical actions by institutional actors. This outline is sketched in the form of a mop-headed tree. The tree is an apt metaphor, perfectly representing the fact that the idea has certain roots and is embedded in particular intellectual and empirical soil. This graph makes clear that the idea was conceived at a key moment and it has developed over time. We can observe that the tree trunk has split into branches and some of these branches have stopped developing or even withered and died. Mop-headed trees are known for their bush-like tops. This is especially appropriate for HS, an idea that does not have one lead proponent. The branches represent trajectories of dissemination and spaces of reproduction. Here four key spaces are identified: 1) the UN network, 
2) academic and expert communities, 3) the NGO community and 4) state-led action. As the figure illustrates, the changing environment and climate have caused a once flourishing tree to start to die. There are only two branches - the UN system and the academy - where the HS idea continues to be reproduced. How this happened is the subject of the following section, which is organised into four parts based on the trajectories and spaces identified as tree branches.

\section{Figure 1: Map of dissemination agents and channels of the HS idea}

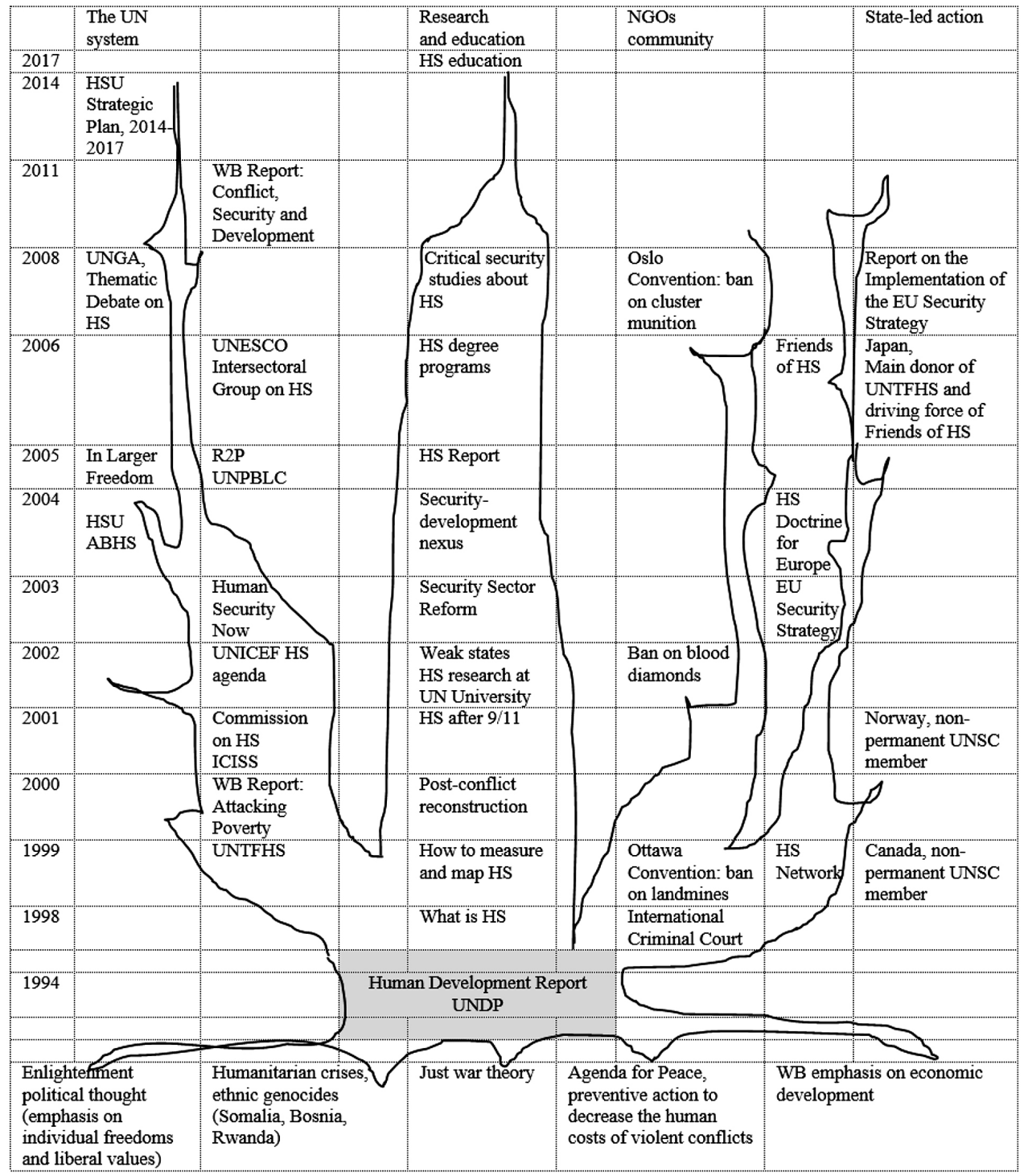




\begin{tabular}{|c|c|}
\hline ABHS: Advisory Board on Human Security & UNGA: United Nations General Assembly \\
\hline EU: European Union & $\begin{array}{l}\text { UNPBLC: United Nations Peacebuilding } \\
\text { Commission }\end{array}$ \\
\hline HSU: Human Security Unit & UNSC: United Nations Security Council \\
\hline $\begin{array}{l}\text { ICISS: International Commission on Intervention } \\
\text { and State Sovereignty }\end{array}$ & $\begin{array}{l}\text { UNTFHS: United Nations Trust Fund for Human } \\
\text { Security }\end{array}$ \\
\hline R2P: Responsibility to Protect & WB: World Bank \\
\hline UNDP: United Nations Development Programme & \\
\hline
\end{tabular}

Source: Author based on Christou 2013; Edström 2011; Martin - Owen 2010; Matlary 2008; Suhrke 1999, 2014; UN 2009; Waisová 2003.

\section{The UN system}

The idea of human security emerged from within the United Nations, and UN bodies, agencies and officials have clearly been key agents in its dissemination and reproduction. The concept arose from the ashes of the Cold War during the debate about the new world order. The end of the Cold War gave rise to spatial transformations that eroded state sovereignty and blurred boundaries both within and beyond nations. The 1990s brought genocide, ethnic cleansing, civil wars and mass starvation in different regions. In such a world, humanitarian language was highly relevant and appealing since it was clear that the "military response was not enough to deal with the new threats and challenges" (Solana 2004)..$^{5}$ Among other things, the HS concept was a response to the loss of meanings previously attached to borders; it emerged amidst new understandings of statehood as the role of states changed from that of protector to predator ( $\mathrm{Tu}$ athail 2000). The idea was first presented by the UN Development Programme (UNDP) in its 1994 Human Development Report. That document defined human security as the freedom of individual human beings from both want and fear. Since 1994, this definition has been at the centre of various debates. There are different positions regarding what should be included with some contending that "wide" definitions are excessive (King - Murray 2002). Nevertheless, the idea of HS (in both its wide and narrower forms) has entered the agenda of many UN bodies and agencies, including the UNHCR, UNICEF, UNESCO and the Office of the UN Secretary General to name only a few (for more examples, see UN 2009).

Supporters of the concept needed time to communicate the HS agenda across the UN institutional framework. By 1999, however, the idea was backed by

5 A similar argument has been made by Sadako Ogata (n.d), who writes that "human security is a new response to complex threats." 
a number of resolutions and it was then institutionalised. HS has been applied to various clusters of issues; particular attention has been paid to women and children in armed conflicts, gender empowerment, post-conflict reconstruction, security sector reform and state-building. To carry out the HS agenda, new bodies and positions have been established. These include the UN Trust Fund for Human Security (1999), the UN Commission on Human Security (CHS/2001), the Human Security Unit at the UN Secretariat (2004), the UNESCO Intersectoral Group on Human Security (2006) and the UN Secretary General Special Advisor on Human Security (2007) (UN 2009). As we will see in the next section, the UN University (UNU) has also played a key role in disseminating and reproducing the concept. Working independently or in cooperation with others, UNU has produced research and literature about human security and offered HS education (Szarzynski 2018). There are now dozens of UN and UNU publications, workshops and even summer schools about human security. In the space of a few years, the HS idea has, thus, spread across the UN system and taken on a life of its own within particular spaces. Individual bodies have produced specific HS knowledge and policies tailored to their sphere. Among the leading examples of this are the UN Environment Programme's analyses of climate change and human security; ${ }^{6}$ UNESCO's projects on the links between HS, culture and education ${ }^{7}$ and UNICEF's work on children and HS. The power of the concept is particularly clear in the case of the UN Trust Fund for Human Security (UNTFHS). Generously financed by Japan, another friend of HS, this fund has the goal of spreading the HS idea within the UN system and beyond and "promot[ing] HS as a methodology for addressing crisis and insecurity" (HSC n.d.; for a critical analysis of UNTFHS, see Goméz 2012). The fund has collected money to support actors who are promoting and implementing the HS idea, and it has channelled assistance to several HS projects (MFAJ 2010). It is also behind the Human Security Handbook (2016), "a guide for practitioners and policy makers who plan to integrate the human security approach into their work" (UNTFHS n.d.).

Closer scrutiny of the dissemination of the HS idea within the UN reveals the vital role of not only institutions but also certain individuals (Martin - Owen 2010). Among these "HS ambassadors" have been Kofi Annan, the former UN Secretary General; Sadako Ogata, the former High Commissioner for Refugees

6 See, e.g., the Disaster and Conflict Programme (http://www.un.org/en/events/environmentconflictday/ pdf/UNEP_conflict_and_disaster_brochure.pdf) and the Nature Opportunities and Human Security Project (https://unemg.org/images/emgdocs/Dialogues/ND5/UNEMG\%20-\%20Biodiversity\%20and\%20 Human\%20Security\%20Dialogue_Final1\%201.pdf).

7 See, e.g., the UNESCO Human Security Project (http://www.unesco.org/new/en/brasilia/about-this-office/ single-view/news/unesco_human_security_project/) and the programme of the UNESCO Chair in Human Security and Regional Development (https://en.unesco.org/unitwin-unesco-chairs-programme). 
and chair of the Human Security Commission; ${ }^{8}$ Amartya Sen, a development doyen who introduced the concept of development as freedom and chaired the Commission on Human Security and Yukio Takasu, the UN Secretary General Special Advisor on Human Security since 2010. These prominent individuals sincerely believed in the benefits of the HS concept and worked as its intellectual champions, promoters and guarantors. Through their activities in the UN and elsewhere internationally, they put HS on the agenda of various UN bodies, the World Bank and many regional (development) organisations. In their efforts to spread the concept outside the UN system, they also gave public speeches ${ }^{9}$ and authored extensive publications (Annan 1998; Ogata - Cels 2003).

In sum, over the last few decades, the UN system has become a space for the co-production of both knowledge and practice about human security. It has also been the main driving force behind the circulation of the HS idea. UN bodies have brought together UN technocrats, NGO representatives and scholars from around the world (CHS 2003). In doing so, they have created a transnational space for experts who produce policy-oriented HS knowledge and share the HS concept beyond the UN system. The UN has become an organisation working at the threshold of change; as such, it has straddled the shifting divide between science in the making and politics in the making. The resulting framework provides a lens through which we can make sense of human experience in a complex world (St Clair 2006). In just a few years, we have seen the establishment of a whole network of HS-engaged bodies, units, commissions, groups and advisory panels and the emergence of many associated visionaries and bureaucrats. The United Nations now houses the most robust and comprehensive system of

8 Sadako Ogata also served as president of the Japan International Cooperation Agency, a Japanese development assistance body, between 2003 and 2011. This background sheds light on Japan's role as one of the forces behind the human security concept. See also the section of this article on state-led HS action.

9 Major speeches by HS champions include the following: Sadako Ogata: “Human Security: a Refugee Perspective." Keynote speech by the United Nations High Commissioner for Refugees at the Ministerial Meeting on Human Security Issues of the "Lysoen Process" Group of Governments. Bergen, Norway, 19 May 1999. <http://www.unhcr.ch/refworld/unhcr/hcspeech/990519.htm>; "Bridging the G8 Kyushu-Okinawa Summit and the UN Millennium Summit: Enabling People to Live in Security." Keynote speech at the International Symposium on Human Security hosted by the Japanese Ministry of Foreign Affairs. Tokyo, 28 July 2000;

"Enabling People to Live in Security." Keynote speech at the International Symposium on Human Security: Bridging the G8 Kyushu-Okinawa Summit and the UN Millennium Summit. Tokyo, 28 July 2000, http:// www.unhcr.ch/refworld/unhcr/hcspeech/000728.htm.

Amartya Sen: "Why Human Security." Presentation at the International Symposium on Human Security hosted by the Japanese Ministry of Foreign Affairs. Tokyo, 28 July 2000;

Yukio Takasu: "Statement by Director-General Yukio Takasu at the International Conference on Human Security in a Globalised World." Ulan-Bator, Mongolia, 8 May 2000, <http://www.mofa.go.jp/policy/ human_secu/speech0005.html>;

"Toward Effective Cross-Sectorial Partnership to Ensure Human Security in a Globalized World." Statement at the Third Intellectual Dialogue on Building Asia's Tomorrow. Bangkok, Thailand, 19 June 2000, <http://www.mofa.go.jp/policy/human_secu/speech0006.html> 
human security bodies, practices, tools and strategies, all of which reproduce the idea of HS both within and beyond the UN (for more details, see United Nations (2009), which describes a human security-related field mission). Significantly, this is a self-perpetuating system, which relies on the self-justifying use of humanitarian language and notions of "people in need."

\section{The academy}

The academic world is a second space where the human security idea has found a home and been spread and reproduced. Scholars and universities are typically understood to be sources of expertise and located outside policy-making circles. This gives them the legitimacy to elevate certain issues. In general, they are understood as producers of expert knowledge and forces behind its circulation. Contrary to conventional wisdom, HS was not the product of an epistemic community in the Haasian-Adlerian sense (Adler - Haas 1992). Rather it was an idea and policy approach which, as we have seen, was explicated in a 1994 UNDP report and in HS research over subsequent years. Within a short time, the academic world was flooded with HS research (Figure 2) and scholars struggled to analyse, understand, theorise, measure, map and criticise HS and debate its disciplinary placement. HS has been discussed as a specific category in border studies (Martin - Owen 2013), a key concept in security studies (Williams 2013), a better way to conceptualise human development (Sen 1999) and a strategic foreign policy instrument (Suhrke 1999). Scholars have also paid attention to human security policy. Publications have, thus, addressed HS's role in a wide range of issues including the 1999 ban on landmines (Adachi 2005); the 2008 ban on cluster munition; steps taken to establish the International Criminal Court in 1998 and 2002 (Rutherford - Brew - Matthew 2003); new approaches to security sector reform and the foreign policy of middle powers. ${ }^{10}$ Across a variety of disciplines, the academic community has shown its fascination with the HS concept, which has been seen as a marker of progress in human-oriented policies. This HS optimism has also prompted academic undertakings: new journals and new research teams and groups have been established; new maps and indices of human (in)security have been produced (see, for example, the Failed States Index, the Human Security Index and the Global Multidimensional Poverty Index); old indexes such as the Human Development Index have been revised and new research reports have been written (the Human Security Reports are a key example). HS has quickly established itself as a policy-oriented field of study which is supported by some governments (Japan, Canada and Norway

10 There is an almost endless list of research of this kind. Some authors have analysed specific HS initiatives and the role of individual states in these projects. These studies sometimes focus on the place of middle powers in the new world order. Other writers query whether the HS concept has produced a new foreign policy identity for old middle powers in the new era of world politics. 
have all offered HS-based research grants) as well as think-tanks and international organisations particularly the UN and the EU (see Figure 1).

A close analysis of the academic dissemination and reproduction of the HS idea highlights the importance of two sites in these processes: policy-oriented research centres and universities. A number of universities in Europe, the United States and Japan have established HS degree programmes (for a sample list, see Appendix 1). The UN University particularly has provided intensive support for HS university education. UNU assisted with the creation of HS degree programmes in countries like Germany, Japan, Costa Rica and Togo, and it helped include HS courses or modules in the educational curricula in several other countries (Szarzynski 2018). These HS degree programmes have mushroomed even as the influence of HS has waned in the policy space. Education is generally understood as an investment in human capital, and in the context of the HS agenda, it has been seen as a way to strengthen human security (Sen 2002). Education is also important for the diffusion of ideas; it has been shown to substantially affect preferences, behaviour and values (Nelles 2006; Ravetz 1996) and may also help or hinder the acceptance of new ideas and norms, which are key for our formation of "cognitive maps" (Axelrod 1976). Individuals educated within the same institution(s) form cohorts or like-minded groups as shared educational experiences give rise to personal networks. Education, thus, helps elites consolidate their power and can influence shared visions of societal development.

The research space is another site where the human security concept has been shared and reproduced. During the second half of the 1990s, an epistemic community emerged which had an overriding conviction about HS's importance and the need for its promotion. Members included the scholars Mary Kaldor, Mary Martin, Amartya Sen, Sabine Alkire, Anuradha Chenoy and Shahrbanou Tadjbakhsh. Among the milestones in their work were the establishment of two research centres: the Civil Society and Human Security Research Unit at the London School of Economics and the Human Security Research Project at the Liu Institute at the University of British Columbia. In a short time, each of these institutes became a support base for academic advisors who were prominent in HS-related policy-making. Kaldor, Alkire, Martin and many others genuinely believed in the benefits of bringing HS into politics; they were active in policy debates and urged policy-makers to take the HS concept seriously (e.g. Kaldor 2007; LSE n.d.b). They prepared a number of advisory reports for the UN, UNESCO, UNDP and the EU and authored various policy papers, articles and speeches on HS. What linked all this work was its representation of HS as a strategy to face new threats and a tool to strengthen the UN and the EU (Study Group on Europe's Security Capabilities 2004; Kaldor - Martin - Selchow 2007).

One particularly interesting development in this regard has been the engagement of scholars from the global South in HS research. The inclusion of these 
scholars was supported widely within the UN system by way of special grants and invitations to attend workshops and conferences and join expert bodies (Hossain - Abiodun 2015; UNESCO 2018). These measures aimed to increase HS expertise in the UN system through the incorporation of the lived experiences of these scholars. At the same time, they were meant to empower scholars from disadvantaged countries.

\section{Figure 2: Number of academic articles on human security published between 1993 and 2017}

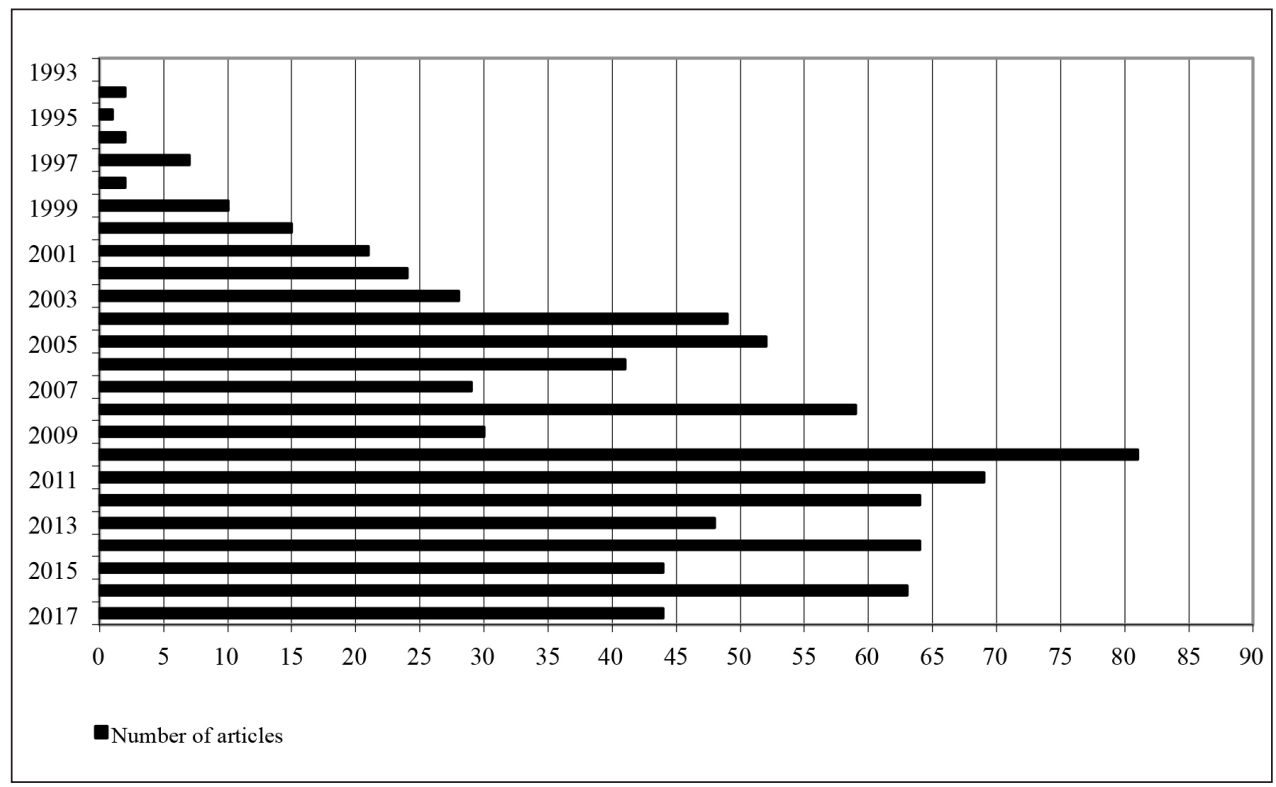

Source: Author based on data from EBSOhost and JSTOR. All data was retrieved from EBSCOhost or JSTOR based on a search of academic peer-reviewed journals for all disciplines. The publication period was from 1993 to 2017. Articles appearing in both databases were only counted once. The criterion for inclusion was the presence of the phrase "human security" in the article title, abstract or keywords.

Note: The graph includes 49 articles about HS that were published in 2004. Of these, 21 were one-page responses featured in the following work: "Comments by 21 Authors. What Is 'Human Security?"' Security Dialogue 35(3) (September 2004): 34 -387.

In recent years, both research and publications about HS seem to have been in decline. This is evident from a search of entries in the JSTOR or EBSCOhost databases where the number of HS-related publications has decreased (Figure 2); the same trend was revealed in an earlier study that drew on data from Google Search and Lexis-Nexis to analyse the use of the phrase "human security" (Krause 2013). Other signs may include the closure of relevant university study programmes (this applies, for example, to Simon Fraser University and the University of British Columbia) and the transformation of HS research centres 
(in 2017, the LSE's Civil Society and Human Security Research Unit was, thus, renamed the Conflict and Civil Society Research Unit). Some study programmes have also been renamed. These developments may reflect changes in world politics in the post-9/11 period. Rather than prolonging seemingly endless debates on the conceptualisation of HS, scholars have shifted their gaze to emerging phenomena such as the security-development nexus and security sector reform.

All in all, we can see that shortly after 1994, scholars and university instructors began to actively share the HS idea, and the academic world was a key site where the concept was reproduced. Scholars published HS-related articles not only in academic journals (Figure 2) but also in newspapers. Many also worked as policy advisors and research-activists who helped policy-makers find the right way to interpret and implement the HS framework. Meanwhile universities reproduced human security discourse through education. Education, a discursive construction of social reality, became important for the fostering and production of HS scholars, bureaucrats and advisors. In their approach to HS, however, these same universities began to steer too close to what Agnew (2007) has called the "religious approach to knowledge in general, that is the creation of like-thinking communities based on [a] transcendental conviction." In the new millennium, "crises of human security" (Martin - Owen 2010) and the declining interest of policy-makers in the idea (including the closure of special grant systems) have naturally affected the research community. Human security has lost its appeal and significance for researchers. Nevertheless the HS framework survives and continues to be reproduced through the education system (see Appendix 1). Education is a long-term undertaking and programmes cannot be changed every year. Human security rhetoric also appeals to open-minded young people with broad interests who are seeking careers in international institutions. This is precisely the group of students that universities wish to attract.

\section{The NGO world}

During the 1990s, state borders blurred, a number of governments were weakened and non-state actors - particularly NGOs - began to play a bigger role. This transformation was apparent both in the academy and in the policy-making sector. Academic interest in NGOs rose exponentially, especially in the area of conflict resolution and across global civil society (see, for example, Aall 1996; Abiew - Keating 2004; Paffenholz - Spurk 2006). ${ }^{11}$ Policy-makers, and especially those in some intellectual circles, promoted the participation of NGOs in world

11 Also revealing in this context is the Global Civil Society Handbook, which was edited by Anheier, Glasius and Kaldor and is currently available through the LSE website: http://www.lse.ac.uk/international-development/conflict-and-civil-society/past-programmes/global-civil-society-yearbook. Between 2001 and 2012, the yearbook was published by the Civil Society and Human Security Research Unit, which became the Conflict and Civil Society Research Unit in 2017. 
diplomacy and particularly humanitarian, development and post-conflict issues (Rutherford - Brew - Matthew 2003).

NGOs had a different role in the dissemination and reproduction of the HS idea to the one played by scholars, teachers and universities. Key non-governmental organisations (for example, Oxfam, Mines Action Canada, Coalition to Ban Landmines, International Alert, Human Rights Watch and Norwegian People's Aid, to give a random sample) did not participate in the debates around HS's conceptualisation and disciplinary placement or its significance in transforming security studies and mapping. Nevertheless, they helped make HS a policy trend. In other words, these NGOs actively attempted to translate the HS idea into practice. They participated extensively in campaigns to ban landmines, cluster munition and the illegal trade in blood diamonds (the Kimberley process). At the same time, they supported the establishment of the International Criminal Court and had wide-reaching roles in programmes to assist child soldiers and women in armed conflict situations and in policies on gender empowerment among other issues. In this way, these NGOs became crucial partners of the UN, EU and states such as Japan, Canada and Norway (for more details, see, for example, Rutherford - Brew - Matthew 2003; Adachi 2005; Cluster Munition Monitor 2010). Within the UN and the EU, NGOs were chosen to be partners in implementing HS initiatives in territories with weak and dysfunctional governments. New platforms bringing together NGOs, states and other internationally engaged actors were established under the banner of human security. These initiatives included the European Centre for Conflict Prevention (2001) (known since 2003 as the Global Partnership for the Prevention of Armed Conflicts Secretariat), the Confederation for Cooperation of Relief and Development NGOs (2003), the Japan Platform and the Japan NGO Unit (2000).

To sum up, NGOs made wide-ranging efforts to popularise HS as a policy approach and they lobbied policy-makers in its name. For these NGOs, the growing acceptance of the HS idea opened the door to the UN, the EU and countries that were fans of the concept including Canada and Japan. At the same time, these developments brought NGOs closer to like-minded policy-makers and enabled them to access new funds and connect different issues (among the typically linked-up topics were demobilisation, demilitarisation and reintegration, and global environmental change and security). Nevertheless, for many NGOs, HS was not the fascinating topic or legitimising tool that it was for academics and some international organisations. It was rather a framework that came and went. These NGOs proceeded as usual, carrying out the same activities as they did under humanitarian, development and human rights (or other) banners. 


\section{State-led action}

A fourth space from which the human security idea has trickled down to different parts of the world and into the realm of world politics has been state foreign policy. The foreign policies of several states have reproduced the concept effectively. Moreover, during the second half of the 1990s, they played the most important role in the rise and reproduction of the HS approach (Waisová 2003). The HS concept, as presented in the 1994 UNDP statement, would most likely have gone unnoticed if several countries had not seized on it and made it a foreign policy priority. Countries which contributed to the concept's dissemination and popularity included Austria, Chile, Jordan, the Netherlands, Slovenia and Switzerland. Another three countries - Canada, Norway and Japan - played an even more instrumental role. While Ottawa and Oslo were prominent promoters of the HS framework in the second half of the 1990s, Tokyo picked up the baton at the beginning of the new millennium.

For Canada, Norway and Japan (and like-minded countries), HS became the key conceptual tool for addressing the growing incidence of civil conflicts around the world and their human costs. It was also a label that legitimised particular humanitarian initiatives (Chandler 2008; Suhrke 2014). Canada and Norway sponsored and worked intensively on the HS agenda both within and outside the UN system. They used the concept to attain important outcomes through the International Criminal Court including assistance to the victims of war crimes and bans on landmines and cluster munition. They also drew on it to launch several UN resolutions on assistance to women and children in armed conflict situations. In 1999, they jointly initiated the Human Security Network, a group of more than ten countries which aimed to spread the HS idea in the international political sphere (Waisová 2003).

Japan was involved in HS work from the mid-1990s, and the concept became one of its top foreign policy priorities at the end of that decade. Nevertheless the country was not a member of the Human Security Network. Instead it went its own way, channelling its HS interest through UN bodies. Japan was a major sponsor of the UN High Commissioner for Refugees and it supported the creation of the Commission on Human Security and appointment of a UN Secretary General Special Advisor on Human Security. It was also the founder and main donor to the UN Trust Fund for Human Security. In 2006, Japan instigated and sponsored an informal forum called "Friends of Human Security." The goal of this group of like-minded members was to "discuss the concept of human security from different angles in order to seek a common understanding of human security and explore collaborative efforts" (MFAJ 2016). Although it was never officially stated, Friends of Human Security was meant to replace Human Security Network, which had ceased to be active. 
It should be stressed here that the efforts to make HS a top foreign policy in Canada, Norway and Japan were highly personalised. The promoters and driving forces behind the concept's dissemination were Lloyd Axworthy (the Canadian foreign minister between 1996 and 2000), Knut Vollebaek (the Norwegian foreign minister between 1997 and 2000) and Obuchi Keizo (between 1997 and 2000, the Japanese foreign minister and then prime minister). These individuals spread the idea of HS at home and abroad (Bosold - Werthes 2005; Axworthy et al. 2014; Edström 2011). However, in democratic politics, the logic of elections inevitably holds sway, and when these three leaders left their offices, support for the HS agenda waned.

It was also evident that for Ottawa, Oslo as well as Tokyo, HS activities were not just an expression of humanitarianism but a way to gain something more from international politics. For Canada and Norway, HS was the key which opened the door to a non-permanent seat in the UN Security Council (for Canada from 1999 to 2000 and for Norway from 2001 to 2002). At the same time, it provided a path to a stronger "middle-power" image and a way to win new partners and more influence in world politics. Put otherwise, HS was a tool for achieving national strategic priorities (Suhrke 1999, 2014). For Japan, the concept offered a way to become an Asian leader in what might be called the politics of goodness and gain credit as a good world citizen. It also reinforced the country's identity as a civilian power to be contrasted with China, whose influence was rising (Edström 2011).

A critical analysis of the troika of states engaged in HS promotion makes clear that today this activism has lost its force. Canada and Norway abandoned the HS ship shortly into the new millennium and Japan's involvement has fallen off since 2009. When reflecting on the waning popularity of the HS concept, we should also bear in mind international developments since the end of the 1990s. The international political scene has been challenged by a number of major transformations: the financial crisis has weakened donors and the global war on terror has made humanitarian language less appealing. Meanwhile interventionism based on humanitarian arguments has been called into question and the Responsibility-to-Protect doctrine cast aside. Development agencies that were once typical HS promoters are now tangled up in security questions including the counter-insurgency and counter-terrorism agenda (Waisová 2010). In this context, as several authors have noted (Martin - Owen 2010; Krause 2013; Suhrke 2014), Canada and Norway have not only lost interest in human security, but erased their trails of HS activity; HS documents and articles have been removed from government websites and bodies formerly responsible for HS policies have been wound up or renamed. While other commentators (MacLean 2009) are less sceptical and argue that HS has been eliminated at a rhetorical level but remains very much present in practice, the rapid decline of both Canadian and Norwegian HS engagement is clear. In 
contrast, Japan's HS involvement has not decreased as sharply but its political, organisational and financial support has petered out. Today, even tracing the history of some HS policy initiatives led by erstwhile supporters and Human Security Network "members" can be challenging because of their silence about their former activities.

Overall, it is clear that state-led action played a significant role in spreading the human security concept among world political actors. This action occurred both within and outside the UN framework. Over the last few years, however, HS has lost its privileged position in state-led action: the Human Security Network has ceased to exist and its website and several projects it supported have also disappeared. ${ }^{12}$ The troika of HS-promoting states and other members of the Human Security Network such as Austria and the Netherlands have terminated their HS projects and no longer support the idea. ${ }^{13}$ Friends of Human Security, the platform supported by Japan, never found the widespread support enjoyed by the Human Security Network. Today, HS survives as a buzzword and policy framework for only a few states. Latvia and Chile have, for example, drawn on the concept to present their social development and democratisation goals; Switzerland applies the HS norm to connect different humanitarian agendas. ${ }^{14}$ In general, however, states have abandoned the space once occupied by the human security agenda: none are promoting the idea and there is no interest in reproducing it.

\section{Conclusion}

In the second half of the 1990s, a tsunami of human security-related activity swept through the UN system, foreign policy agendas and the NGO community as well as the academic world. HS was seen as a unique and innovative post-Cold War era tool for managing the new security environment. How did HS become such a vital concept? Who promoted it and what methods did they use? How was the idea reproduced in world politics? These are the issues that I have analysed in this article. I have examined the institutional and historical dynamics and driving forces behind the dissemination and reproduction of the HS concept as well as the roles of various agents in these activities. In keeping with the structure of this analysis, this conclusion is presented in two stages:

12 Those projects include the HS Bulletin, which was published by the Canadian Consortium on Human Security, and the Human Security Gateway, a database of HS-related research and information.

13 This shift can be seen, for example, from the absence of recent human security projects including publications on the European Training and Research Centre for Human Democracy (ETC Graz) website: http://www.etc-graz.at/typo3/index.php?id=103.

14 For more information, see the Human Security Divison of the Swiss Federal Department of Foreign Affairs: https://www.fdfa.admin.ch/eda/en/home/fdfa/organisation-fdfa/directorates-divisions/directorate-political-affairs/hsd.html. 
first I evaluate the observations concerning each of the spheres addressed and then I consider the interplay between these spaces.

Examining the UN system shows us that the UN was the place where the human security idea was born. It was also the key institutional platform used to promote, disseminate and reproduce the HS concept at global level. Given the UN's complex institutional structure and agenda and its efforts to find effective new instruments to manage post-Cold War humanitarian crises, it was a unique environment for the reproduction of the HS concept. This was an ideal space from which the idea could trickle down into politics. The UN became a space for the co-production of knowledge and practice. After the original innovative potential of HS was exhausted, however, UN bureaucrats were left with only a shadow of their former agenda. Today HS bodies, boards, units, funds and commissions still technically exist, but many of them have vague agendas, and the concept is less effective within the UN system. Instead, it is associated with missions and projects that are rehashed in endless workshops, conferences, summer schools and programmes, and it features in hollow declarations and past resolutions (e.g. declarations on the Responsibility to Protect) which are not used or only applied selectively. Many missions and projects have a title that combines "human security" with other issues, but the phrase could very easily be replaced with "humanitarian," "human rights," "development" or "counter-insurgency" depending on the project goal. As a concept, HS seems to have been hollowed out. Over the last few years, it has become an empty phrase within the UN system and a tool for the self-preservation and self-justification of certain bureaucratic bodies and technical structures.

Analysing the academic world reveals that scholars and universities are not very different from UN staff when it comes to their capacity for critical self-reflection. While academics can incorporate new problems into their research, it may take them a long time to move on from a research project (this has also been my experience in carrying out this study). In fact, the human security concept gave social science scholars unprecedented access to and influence in policy-making circles. Scholars became intellectual sponsors of the concept. This new cadre of consultants, transnational advisors and researcher-activists spoke authoritatively on behalf of the UN, the EU and state supporters of HS and, thus, legitimised their policies. The alliance between scholars and policy-makers rose to a new level when the political establishment provided special funds for the establishment of university HS research units and centres. Several prominent scholars settled into high-level advisory or managerial positions. The peak of this frenzy produced a wave of HS degree programmes at universities. The transnational dissemination of HS as certified knowledge took place through research publications, research grants and policy consultancies along with HS education for those wishing to work "internationally [...] and look for [...] careers in NGOs, government aid organizations, UN organizations and 
private consultancy firms that administer and implement development and disaster aid" (Aarhus University n.d.). While a number of non-Western states were resistant to HS ideas and practices (Acharya 2001; UNESCO 2008), the concept attracted scholars from Africa, Asia and other non-Western regions and it featured in their research (see, for example, Acharya 2001; Hossain Abiodun 2015; UNESCO 2008). Writing on these matters gave these scholars the chance to become part of an international HS epistemic community, obtain research grants from international institutions and join international consultancy, expert and research groups. For the groups and bodies in question, the inclusion of members from high-risk regions that lacked human security was a self-legitimising and self-authorising move. When the interest in HS dissipated in policy circles, both the demand for HS scholarship and the financial resources for HS research and publications declined. Naturally, the academic world reflected changes in world politics, and new problems such as the global war on terror and counter-insurgency rose to the top of the academic agenda.

An assessment of the NGO community's relationship with the human security framework shows that NGOs were only touched by the concept in a limited way. NGOs were involved in some HS-related activities but they did not set out to spread the concept; any such dissemination was just a side effect. Initially, NGOs were not particularly interested in HS. This was partly because of the traditional associations between "security" and state institutions and international security organisations. It was also because debates about HS's conceptualisation went beyond the NGOs' sphere of interest. They had no special need for the HS approach and were content with using terms like "humanitarian," "human rights," "poverty," "underdevelopment" and "empowerment" to frame their activities. Later, the NGO community joined in the advocacy for various human security-based measures such as the ban on landmines. "Human security" was used as a way to identify projects that aimed to help people rather than states. It was also meant to highlight projects that integrated competing agendas for the sake of better coordination and cooperation, whether strategically or in the field.

Turning to state-led action, it is clear that three states - Canada, Japan and Norway - were the driving forces behind the rise and reproduction of the human security concept. Ironically, the territoriality of states made it inevitable that however innovative and attractive the HS idea was, they could not absorb its deterritorialising agenda. Canada, Japan and Norway adopted the concept selectively and in ways that reflected their own foreign policy culture and goals. In all three states, we may conclude that the HS approach was used to help people in need while also pursuing national strategic priorities. Each country had its own version of HS, which it spread and reproduced thorugh particular policy projects. Today, in contrast, human security is not a foreign policy priority for any of these states. Nevertheless, as in the NGO community, HS-based practices have not disappeared entirely from foreign policy. These practices are simply 
framed differently - for example, as "human rights," "security-development nexus" or "whole-of-government" initiatives. Martin and Owen (2010) describe this change as the rise of "second generation human security."

As we have seen, two institutional spaces were responsible for the dissemination and reproduction of human security as a concept and policy approach: the United Nations and state foreign policy departments in Canada, Japan and Norway. The academic world reflected all the ups and downs of HS-based practices and served mainly as a space for the circulation and reproduction of HS as knowledge. Scholars spoke authoritatively on behalf of clients like the UN and the EU and universities generated (and continue to produce) elite groups of HS bureaucrats. While it may not have been completely intentional, a mutually beneficial relationship seems to have arisen between UN technocrats and universities. This relationship continues to provide the UN with a particular humanitarian agenda, bodies and personnel; it also gives universities a ready customer for the research and human capital they produce.

When reflecting on the spread of the human security concept, the key role of several distinguished individuals cannot be ignored. Kofi Annan, Lloyd Axworthy, Mary Kaldor, Amartya Sen, Sadako Ogata and Knut Vollebaek each conveyed the HS message in a unique way. As they "travelled" between political positions and international or academic offices, they brought the HS agenda with them. The long-term engagement of these individuals was crucial for the establishment of particular systems of institutional dissemination.

In conclusion, over the last three decades, we have seen a major investment of time, enthusiasm and funds in human security-related infrastructure, projects and institutions. Combined with the significant personal involvement of policy-makers and scholars, this has led to the institutionalisation of a HS industry and the professionalisation of a technocratic managerial elite which maintains HS within the UN system. Despite this trend, the idea of HS is now ailing. It has been replaced by alternative frameworks such as environmental peacebuilding and the security-development nexus. At least for now, these are proving to be more alluring. 
Appendix 1: List of universities where HS can be studied within a degree
programme (random sample ordered alphabetically by country name)

\begin{tabular}{|c|c|c|c|c|}
\hline Country & University & Department(s) & Programme title & Degree \\
\hline Canada & \begin{tabular}{|l|}
$\begin{array}{l}\text { Royal Roads } \\
\text { University }\end{array}$ \\
\end{tabular} & Humanitarian Studies & HS and Peacebuilding & MA \\
\hline Costa Rica & University for Peace & N/A & HS & MA \\
\hline Denmark & Aarhus University & $\begin{array}{l}\text { Culture and Society; } \\
\text { Anthropology; Bioscience } \\
\text { (Danish Centre for Food } \\
\text { and Agriculture, Danish } \\
\text { Centre for Environment } \\
\text { and Energy) }\end{array}$ & HS & MA \\
\hline Germany & University of Bonn & $\begin{array}{l}\text { Jointly organised by the } \\
\text { Department of Geography } \\
\text { and the UN University in } \\
\text { Bonn }\end{array}$ & $\begin{array}{l}\text { Geography of } \\
\text { Environmental Risks and HS }\end{array}$ & M.Sc. \\
\hline Japan & $\begin{array}{l}\text { University of Tokyo, } \\
\text { Komaba }\end{array}$ & $\begin{array}{l}\text { Five departments of the } \\
\text { Graduate School of Arts } \\
\text { and Sciences (Language } \\
\text { and Information Sciences, } \\
\text { Interdisciplinary Cultural } \\
\text { Studies, Area Studies, } \\
\text { Advanced Social and } \\
\text { International Studies } \\
\text { and Multi-Disciplinary } \\
\text { Sciences) } \\
\end{array}$ & Graduate Programme in HS & MA, PhD \\
\hline Japan & Tohoku University & $\begin{array}{l}\text { Graduate Schools in } \\
\text { Agricultural Science, } \\
\text { Medicine, International } \\
\text { Cultural Studies and } \\
\text { Environmental Studies }\end{array}$ & $\begin{array}{l}\text { International Joint } \\
\text { Educational Programme } \\
\text { in HS }\end{array}$ & $\mathrm{PhD}$ \\
\hline Japan & Kyoto University & \begin{tabular}{|l|} 
Urban Human Security \\
Engineering Education and \\
Research Center
\end{tabular} & $\begin{array}{l}\text { Integrated Engineering } \\
\text { stream: } \mathrm{HS} \text { and Engineering }\end{array}$ & $\begin{array}{l}\text { MA, PhD } \\
\text { summer } \\
\text { schools } \\
\end{array}$ \\
\hline Spain & $\begin{array}{l}\text { Universitat } \\
\text { Autònoma de } \\
\text { Barcelona }\end{array}$ & \begin{tabular}{|l|} 
Public Law and Legal \\
History Studies (offered in \\
collaboration with \\
Universitat del \\
Mediterraneo di Reggio \\
Calabria and Universidad \\
UMASS Lowell de Boston) \\
\end{tabular} & HS and Global Law & $\mathrm{PhD}$ \\
\hline Togo & University of Lomé & $\begin{array}{l}\text { Programme supported } \\
\text { by the German Federal } \\
\text { Ministry for Education } \\
\text { and Research and the UN } \\
\text { University }\end{array}$ & Climate Change and HS & MA \\
\hline UK & $\begin{array}{l}\begin{array}{l}\text { University of East } \\
\text { London }\end{array} \\
\end{array}$ & School of Social Sciences & $\begin{array}{l}\text { Conflict, Displacement and } \\
\text { HS }\end{array}$ & MA \\
\hline USA & Tufts University & $\begin{array}{l}\text { Fletcher School (Institute } \\
\text { of HS) }\end{array}$ & Certificate in HS & $\begin{array}{l}\text { BA, MA, } \\
\text { PhD }\end{array}$ \\
\hline
\end{tabular}




\begin{tabular}{|l|l|l|l|l|}
\hline USA & $\begin{array}{l}\text { University of } \\
\text { Bridgeport }\end{array}$ & $\begin{array}{l}\text { College of Public and } \\
\text { International Affairs }\end{array}$ & Criminal Justice and HS & $\begin{array}{l}\text { BA } \\
\text { MA }\end{array}$ \\
\hline USA & $\begin{array}{l}\text { University of } \\
\text { Baltimore }\end{array}$ & N/A & Global Affairs and HS & MA \\
\hline USA & $\begin{array}{l}\text { University of } \\
\text { Pittsburg }\end{array}$ & $\begin{array}{l}\text { Graduate School of Public } \\
\text { and International Affairs }\end{array}$ & $\begin{array}{l}\text { International Development } \\
\text { with a HS major }\end{array}$ & MA \\
\hline USA & $\begin{array}{l}\text { Embry-Riddle } \\
\text { Aeronautical } \\
\text { University }\end{array}$ & N/A & HS and Resilience & M.S. \\
\hline USA & $\begin{array}{l}\text { University of } \\
\text { Massachusetts }\end{array}$ & $\begin{array}{l}\text { McCormack Graduate } \\
\text { School of Policy and } \\
\text { Global Studies }\end{array}$ & Global Governance and HS & PhD \\
\hline
\end{tabular}

Source: Author based on individual university websites ${ }^{15}$

\section{References}

Aall, Pamela (1996): Nongovernmental Organizations and Peacemaking, in Crocker, Chester Hampson, Fen - Aall, Pamela, eds. Managing Global Chaos. 433-444, United States Institute of Peace Press.

Aarhus University (n.d.): Human Security: Career, http://kandidat.au.dk/en/humansecurity/

Abiew, F. K. - Keating, T. (2004): Defining a Role for Civil Society, in Keating, T. - Knight, W.A. Building Sustainable Peace. 93-117, University of Alberta Press.

Acharya, Amitav (2001): Human Security: East versus West. International Journal 56 (3): 442-60.

15 Royal Roads University (http://www.royalroads.ca/prospective-students/master-arts-human-security-and-peacebuilding);

University for Peace (https://www.upeace.org/academic/academic-departments/peace-and-conflict-studies/international-peace-studies);

Aarhus University (http://kandidat.au.dk/en/humansecurity/);

University of Bonn (https://www.uni-bonn.de/studying/international-students/international-degree-programs/natural-sciences-and-mathematics/copy_of_master2019s-program-in-computer-science);

University of Tokyo (http://www.c.u-tokyo.ac.jp/eng_site/info/academics/grad/programs/hsp/);

Tohoku University (http://www.human-security.tohoku.ac.jp/);

Kyoto University (http://hse.gcoe.kyoto-u.ac.jp/);

University of Barcelona (http://www.uab.cat/web/postgraduate/phds/all-phd-programmes/general-information/human-security-and-global-law-1345467765430.html?param2=1345674114472);

University of Lomé (http://www.wascal.org/graduate-programmes/climate-change-and-human-security/); University of East London (https://www.uel.ac.uk/postgraduate/ma-conflict-displacement-and-human-security);

Tufts University (http://fletcher.tufts.edu/Academic/Courses/Fields-of-Study/Human-Security);

University of Bridgeport (http://www.bridgeport.edu/academics/undergraduate/criminal-justice-and-human-security-b/);

University of Baltimore (http://www.ubalt.edu/cpa/graduate-programs-and-certificates/degree-programs/global-affairs-and-human-security/);

University of Pittsburg (http://www.fordinstitute.pitt.edu/);

Embry-Riddle University (https://erau.edu/degrees/master/human-security-resilience/)

University of Massachusetts (https://mccormack.umb.edu/academics/crhsgg/programs/global-governance-and-human-security-phd). 
Adachi, Kenki (2005): Why Japan Signed the Mine Ban Treaty: The Political Dynamics Behind the Decision. Asian Survey 45(3): 397-413.

Adler, E. - Haas, P. M. (1992): Conclusion: Epistemic Communities, World Order and the Creation of a Reflective Research Program. International Organisation 46(1): 367-390.

Agnew, John (2007): Know-Where: Geographies of Knowledge of World Politics. International Political Sociology 1(2): 138-48.

Annan, Kofi (1998): The Quiet Revolution. Global Governance 4(2):123-138.

Axelrod, R. (1976): Structure of Decision: The Cognitive Map of Political Elites, Princeton University Press.

Axworthy, L. - Vollebaek, K. - Kuhnle, S. - Peou, S. (2014): Introduction: Human Security at 20-Lysoen Revisited. Asian Journal of Peacebuidling 2(2): 143-149.

Bosold, David - Werthes, Sascha (2005): Human Security in Practice: Canadian and Japanese Experiences. IPG-International Politics and Society 1: 84-101.

Chandler, David (2008): Human Security: The Dog That Didn't Bark, Security Dialogue 39(4): 427-438.

Christou, George (2013): The European Union's Human Security Discourse: Where Are We Now? European Security 23(3): 364-81.

CHS (Commission on Human Security) (2003): Human Security Now. New York: Commission on Human Security.

Cluster Munition Monitor (2010): Mines Action Canada, http://www.the-monitor.org/media/1641847/CMM_2010_pdf.pdf

Derian, James Der (1987): On Diplomacy: A Genealogy of Western Estrangement. Blackwell.

Dissent (2007): New Wars and Human Security. An Interview with Mary Kaldor. Winter: 14-35.

Edström, Bert (2011): Japan and Human Security: The Derailing of Foreign Policy Vision. Asia Paper, March 2011. Institute for Security and Development Policy: Stockholm.

Finnemore, Martha - Sikkink, Kathryn (1989): International Norm Dynamics and Political Change. International Organization 52(4): 887-917.

Foucault, M. (1977): Discipline and Punish. The Birth of the Prison. Vintage Books.

Gasper, Des (2004): Securing Humanity: Situating "Human Security" as Concept and Discourse. Journal of Human Development and Capabilities 6(2): 221-45.

Gille, Z. - Riain, S. Ó. (2002): Global Ethnography. Annual Review of Sociology 28(1): 271-295.

Gómez, O. (2012): What is a human security project? The experience of the UN Trust Fund for Human Security. Global Change, Peace \& Security 24(3): 385-403

Gould, Jeremy (2014): Positionality and scale: Methodological issues in the ethnography of aid. Occasional Paper 24: 263-90.

Hossain I. - Abiodun, A.I. (2015): Human Security in a Globalised World: Concepts and Issues for the Muslim World, in Hasan, S., ed. Human Security and Philanthropy. Nonprofit and Civil Society Studies (An International Multidisciplinary Series), Springer. 
HSC (Human Security Course) (n.d.): E-learning cource on Human Security. http://humansecuritycourse.info/.

Kaldor, M. (2007): Human Security: Reflections on Globalization and Intervention. Cambridge, Polity Press.

Kaldor, M. - Martin, M. - Selchow, S. (2007): Human security: a new strategic narrative for Europe. International Affairs 83: 273-288.

LSE (London School of Economics) (n.d.a): About the Conflict and Civil Society Research Unit. http://www.lse.ac.uk/international-development/conflict-and-civil-society/about

LSE (n.d.b): Professor Mary Kaldor: About me. http://www.lse.ac.uk/international-development/ people/mary-kaldor

King, G. - Murray, Christopher J.L. (2002): Rethinking Human Security. Political Science Quarterly 116: 585-610.

Krause, Keith (2013): Critical Perspective on Human Resources, in Martin, Mary - Owen, Taylor, eds. The Routledge Handbook of Human Security, 76-93, Routledge.

MacLean, George A. (2009): The Future for Human Security in Canada: Evaluating "Change" in Foreign Policy. Journal of Human Security 5(3): 58-71.

Martin, M. - Owen, T. (2010): The second generation of human security: Lessons from the UN and EU experience. International Affairs 86: 211-224.

Matlary, J. (2008): Much Ado about Little: The EU and Human Security. International Affairs (Royal Institute of International Affairs 1944-) 84(1): 131-143.

MFAJ (Ministry of Foreign Affairs Japan) (2010): Evaluation on Multilateral ODA: The UN Trust Fund for Human Security. Summary.

MFAJ (2016): Friends of Human Security, http://www.mofa.go.jp/policy/human_secu/friends/ index.html

Nelles, W. (2006): Bosnian education for security and peacebuilding? International Peacekeeping 13(2): 229-241.

Newman, Edward (2010): Critical human security studies. Review of International Studies 36: 77-94.

Nietzsche, F. (2006/1887): On the Genealogy of Morality. Cambridge University Press.

Ogata, Sadako (n.d.): Human Security - A new response to complex threats. Huffington Post, https://www.huffingtonpost.com/A-View-from-the-United-Nations-/human-security----a-new-r_b_3195120.html.

Ogata, S. - Cels, J. (2003): Human Security: Protecting and Empowering the People. Global Governance 9(3): 273-282.

Owen, Taylor (2010): Human Security: A Contested Contempt, in Burgess, J. Peter, ed., The Routledge Handbook of New Security Studies, 39-49, Routledge.

Paffenholtz, T. - Spurk, Christoph (2006): Civil Society, Civic Engagement, and Peacebuilding, Washington, D.C.: World Bank, Social Development Papers, Conflict Prevention and Reconstruction No. 36 (October). 
Paris, Roland (2001): Human Security: Paradigm shift or hot air? International Security 26 (2): 87-102.

Price, Richard M. (1997): The Chemical Weapons Taboo. Cornell University Press.

Ravetz, J. (1996): Scientific Knowledge and its Social Problems. Transaction Publishers.

Rutherford, K.R - Brem, S. - Matthew, R.A., eds. (2003): Reframing the Agenda. The Impact of NGO and Middle Power Cooperation in International Security Policy. Westport, CT: Praeger.

Sen, Amartya (1999): Development as Freedom. Oxford University Press.

Sen, Amartya (2002): Basic Education and Human Security. Unpublished paper, http://afed. itacec.org/document/Education\%20and\%20Human\%20Security.pdf.

Solana, Javier (2004): EUHR Solana responds to report by Study Group on Europe's Security Capabilities. EU Delegation to the UN. http://eu-un.europa.eu/euhr-solana-responds-to-report-by-study-group-on-europes-security-capabilities/

St Clair, Asunción L. (2006): Global Poverty: The Co-Production of Knowledge and Politics. Journal of Global Social Policy 6(1): 57-77.

Stubbs, Paul (2014): Globalisation, memory and consultancy: Towards a new ethnography of policy advice and welfare reform. Occasional Paper 24: 175-98.

Study Group on Europe's Security Capabilities (2004): A Human Security Doctrine for Europe The Barcelona Report of the Study Group on Europe's Security Capabilities, Barcelona, Spain.

Suhrke, Astrid (1999). Human security and the interest of states. Security Dialogue 30: 265-276.

Suhrke, Astri (2014). Human Security 15 Years after Lysøen: The Case against Drone Killings. Asian Journal of Peacebuilding 2(2): 185-98.

Szarzynski, J. (2018): Personal interview at UN University, Bonn, July 5.

Tuathail, Geróid Ó. (2000): The Postmodern Geopolitical Condition: States, Statecraft, and Security at the Millennium. Annals of the Association of American Geographers 90(1): 166-78.

United Nations (2009): Human Security in Theory and Practice: An Overview of the Human Security Concept and the United Nations Trust Fund for Human Security. New York: United Nations, Human Security Unit.

UNESCO (2008): Human Security. Approaches and Challenges. Paris: UNESCO.

UNTFHS (UN Trust Fund for Human Security) (n.d.): About the Trust Fund. http://www.un.org/ humansecurity/\#

Vucetic, S. (2011): Genealogy as a research tool in International Relations. Review of International Studies 37(3): 1295-1312.

Waisová, Šárka (2003): Human Security: the Contemporary Paradigm? Perspectives no. 20: 58-72.

Waisová, Šárka (2010): The Transformation of Canada's Development Policy through the Security-Development Approach, in Hynek, N. - Chandler, D., eds., Canada's Foreign Security Policy: Soft and Hard Strategies of Middle Power, 81-99, Don Mills, ON: Oxford University Press.

Williams, P. D., ed. (2013): Security Studies: An Introduction, 2nd Edition. London: Routledge. 
Šárka Waisová studied International Relations and International Territorial Studies at the Charles University in Prague/Czech Republic, Phillips-Universität in Marburg and Technical University of Dresden/Germany. She holds the PhD in Political Science and European Studies from the Palacky University in Olomouc/Czech Republic and habilitation (associate professor degree) in Political Science with the focus on Security studies from the Masaryk University in Brmo/Czech Republic. She works as Associate Professor and guarantee of study programmes International Relations (M.A. and PhD. level) at the Department of Political Science and International Relations, University of West Bohemia in Pilsen/Czech Republic. In 2016-2018 she was an International Chair at the National University of Public Service in Budapest/ Hungary, she realised also longer research stays in Taiwan, U.S. and Canada. In her research she is concerned with foreign policy, security, conflict resolution and knowledge diffusion. She is author or co-author of about one hundred scholar publications. Among the most recent we can mention books Environmental cooperation as a tool for conflict transformation and resolution (Lexington Books, 2017), The role of Taiwanese civil society organizations in Cross-Strait relations (Routledge, 2018) or Foreign, Security and European Policy of Visegrad Group (eds. together with L. Cabada). E-mail: sarka.waisova@mup.cz and waisova@kap.zcu.cz 